\title{
GREEN INFRASTRUCTURE EMBODY AN EXCEPTIONAL SPIRITUAL RELATIONSHIP OF PEOPLE WITH NATURE: CULTURAL LANDSCAPE, IMPLICATION FOR SUSTAINABLE DEVELOPMENT
}

\author{
Assist. Prof. Dr. Fereshteh Habib \\ fereshteh_habib@yahoo.com \\ fereshteh.habib@emu.edu.tr \\ fereshtehhabib@gau.edu.tr
}

KEY WORDS: place identity, cultural landscape, green infrastructure, sustainable development, Pedhieos River

\begin{abstract}
:
The major thrust of this study is to identify a way to improve the physical condition of greenway corridors in urban areas to better serve the multi-objectives of greenways for sustainable communities, based on a literature review and case study. Pdios River has been introduced, because of several factors; it is geographically representative of the region and one of the main natural land marks in Lefkosa, capital city of Cyprus. This paper demonstrates that cultural landscapes are part of the city's wealth and producing healthy ecosystem as city's brand, with a proper designed green infrastructure planning, conservation and preservation, promote place identity in identified markets. Nearly all major cities have been built along river corridors. River corridors are being focused on as important natural networks as well as cultural and recreational resources. Lefkosa Creek passes through the historical old city of Lefkosa and another historic site so it provides historical heritage and protects cultural values. It can work as a recreational, educational corridor with attraction of the cultural, historical fabrics as well as ecologically significant corridors. This research paper presents the guidance report on how to develop the methodological work linked with green infrastructure to promote place identity by emphasis on conservation and preservation green infrastructure as cultural landscape as implications for sustainable development.
\end{abstract}

\section{MANUSCRIPT}

\subsection{Introduction}

This study provides empirical information useful in understanding how greenway trails in urban areas are perceived to develop designs that would improve the physical qualities of these trails. The study has two objectives. The first is to investigate with conceptual dimensions related to topics in order to make the required link between key words to understand the impact of culture on green infrastructure as transition of sustainability in searching for place identity. The second objective is to investigate the relationship between pieces and works to put all the pieces together in order to lead us into a design, as an example, Lefkosa Creek(Pedhieos River) has been introduced, because of several factors, on the one hand it is geographically representative of the region ,the Lefkosa creek watershed faces water quality and environmental challenges, it is one of the main natural land marks in Lefkosa; on the other hand, as a cultural landscape which became a vacant site and disused premises is a part of city's wealth, and provide a sense of place and identity; they map our relationship with the land over time; and they are part of our national heritage and each of our lives, a training ground and experimental zone for the future city. It is a physical reflection of the city's history. Reintegrating such spaces in the city, creating paths between them, reconnecting disparate urban spaces is something that can actively promote. Currently it has no market value. This study demonstrates that objectives, a healthy ecosystem, and sustainable urban aesthetic can be reached with a proper design in which the arts combined with other users. Amusement gardens with a juxtaposition of nature, art, food, dance music and dinner in a complex which Cultural ceremonies can be hold over there too. This approach is theoretical one so; a combination of documentary research and perceptive method could prove to be appropriate. In the process of devising theories, studying the urban planning texts related to the subject of study play a key role.

\subsection{Place identity}

Globalization is realized in uniformity of manners of behaviour but it is also coupled with plurality in identity that is manifested in various forms. Since modern communication techniques are costly and the majority of computer programs are American, the global village will be formed based on Western patterns. Today, non-Western civilizations show identity-safeguarding reactions against the waves of globalization, a mighty wave that no civilization is able to resist against or escape from it. We know that the process of globalization does not spell the end of ethnic, regional and national cultures. In contrast to globalization of the phenomena, bigoted nationalistic moves are revived. Allegiance to tribes and ignorant tendency to cultural identity are brought back to life. The cultural rhythm of the world is polyphonic and we are facing combinations and associations, the emergence of new thoughts and perfection of the ancient views. Myth is advancing shoulder to shoulder with wisdom. The most primitive culture is the essence of the most complicated technologies. All stages of consciousness, from Neolithic to the age of information, are seeking their rights. Their emergence puts forth another problem, i.e. their coexistence. Traditional thought is unable to get out of itself to criticize itself, but modernity is able to move on the heights of various levels of understanding and reflect a true evaluation with dependency on a certain culture. Globalization is an uncontrollable and irrevocable movement that came to being with the assistance of open market and development of transport and communications technology. In this age boundaries were removed, free turnover 
of properties and movement of individuals were facilitated, shocks were imposed on national devotion, and cultural identities were violated. The modern-day man has a fear in the depth of his heart. If he is the head of state, he will accidentally consult the palm readers and fortune tellers, and if he is a scientist, he likes to mediate on Tao physics and he believes in delicate things and metempsychosis. The modern-day man does not trust his wisdom and enlightenment. This is not spirituality anymore; it is the return of superstition. We are experiencing a schizophrenic behaviour. Accompanying with Japanese hightech, we are going to prove "Chi" power in the school of Zen. New methods of education are introduced in cultural pluralism. Despite awareness on original identity, a new identity is created based on consensus and agreement. Instead of using pluralism we'd better use unity in multicipility, and then new and halfway education will have a new definition for itself. Identity as a fixed tribal unit will be rejected and from this viewpoint, identity is varied and variable in nature with a specific historical status, that is to say, it is the result of various changes, multipleform and continuous distinctions. The followers of cultural pluralism attack this identity seeking nationalism. The most outrageous and critical attacks were originated by Foucault and Derrida. They bluntly attribute all valuation to the criteria imposed by the power structures.

With respect to the above, it becomes clear that the concept of identity in modern-day world is very complicated. Since the form created by man and his artificial atmosphere is the result of his thinking process and various forms and disciplines result from their way of mixing and because this thought has been organized in a highly complex cultural framework, if we believe in the role of city planner as a subjective factor in promoting the quality of city structure, we must identify the logic behind these relations in order to be able to expand this logic and obtain a conscious recognition for creating desired environment. Therefore, with respect to the studies of this paper in connection with the concept of identity and its multi-dimensional aspects, it is difficult to define a concrete meaning for place identity, but in general place identity is a reflection of indigenous identity, religious identity and global identity of its users.

\subsection{Cultural landscape}

Cultural Landscapes have been defined by the World Heritage Committee as distinct geographical areas or properties uniquely "..represent the combined work of nature and of man..".

The World Heritage Committee has identified and adopted three categories of cultural landscape, ranging from (I) those landscapes most deliberately 'shaped' by people, through (II) full range of 'combined' works, to (III) those least evidently 'shaped' by people (yet highly valued). The three categories extracted from the Committee's Operational Guidelines, are as follows:

(I) "A landscape designed and created intentionally by man";

(II) An "organically evolved landscape" which may be a "relict (or fossil) landscape" or a "continuing landscape";

(III) An "associative cultural landscape" which may be valued because of the "religious, artistic or cultural associations of the natural element". Cultural landscape, cultivated terraces on lofty mountains, gardens, sacred places ..., testify to the creative genius, social development and the imaginative and spiritual vitality of humanity. To reveal and sustain the great diversity of the interactions between humans and their environment, to protect living traditional cultures and preserve the traces of those which have disappeared, these sites, called cultural landscapes, have been inscribed on the World Heritage List.
These certain sites reflect specific techniques of land use that guarantee and sustain biological diversity. Others, associated in the minds of the communities with powerful beliefs and artistic and traditional customs, embody an exceptional spiritual relationship of people with nature. There exist a great variety of Landscapes that are representative of the different regions of the world. Combined works of nature and humankind, they express a long and intimate relationship between peoples and their natural environment. Lands were then regarded to have been shaped by natural forces, and the unique details of such landshaffen (shaped lands) became themselves the subject of 'landscape' paintings (Gibson, 1989). A 2006 academic review of the combined efforts of the World Heritage Committee, multiple specialists around the world, and nations to apply the concept of 'cultural landscapes', observed and concluded that:"Although the concept of landscape has been unhooked for some time from its original art associations ... there is still a dominant view of landscapes as an inscribed surface, akin to a map or a text, from which cultural meaning and social forms can simply be read"(Pannell, 2006). Within academia, any system of interaction between human activity and natural habitat is regarded as a cultural landscape. In a sense this understanding is broader than the definition applied within UNESCO, including, as it does, almost the whole of the world's occupied surface, plus almost all the uses, ecologies, interactions, practices, beliefs, concepts, and traditions of people living within cultural landscapes(Flower,2003). Neglect and inappropriate development put our irreplaceable landscape legacy increasingly at risk. Too often today's short-sighted decisions threaten the survival and continuity of our shared heritage. It is everyone's responsibility to safeguard our nation's cultural landscapes. The ongoing care and interpretation of these sites improves our quality of life and deepens a sense of place and identity for future generations.

\subsection{Sustainable development}

Development is considered a multi-dimensional process embracing not only economic but also social, political, cultural and environmental factors. It is a "continuous and positively evaluated change in the totally of human experience"(Harrison,1998)The concept of sustainable development means efficient use of resources, land, built space and energy and transition from using non-renewable to renewable resources. It means recycling materials and minimizing waste and pollution. It also includes limiting processes detrimental to heritage, nature and health and social equity. Finally, the concept rests on three pillars: environmental, social, and economic. In contrast to urban ecology, sustainability has no single theoretical starting point. The starting point for those working within the concept of urban ecology usually is fundamental environmental values and beliefs. They move upwards, mostly from local initiatives, with small scale projects and low level technology. Those employing the concept of sustainability have a pragmatic starting point and move along more rationalistic paths from the top downwards in large scale initiatives often involving a higher level of technology with responsible experts .The basic values in this perspective are to a large extent with a somewhat greater emphasis on the health and well-being of humans. The urban development of frontier economics leads to a number of environmental damages in the form of hazardous pollution, loss of recreational areas, etc. Within the environmental protection perspective, the need to counteract such damages is recognized if these damages are a threat to the health and well-being of the 
habitants. Through political tradeoffs one seeks to create an acceptable balance between growth and protection. In contrast to modernization theory, sustainable development gives primacy to the satisfaction of basic needs, such as food, shelter, healthcare and education, although economic growth remains a fundamental prerequisite-the pollution of poverty must first be addressed before development in form can occur. Thus, sustainable development proposes a long-term, holistic perspective that espouses equity, choice, political freedom (from dependency), cultural integrity and development within environmental parameters (Sharply, 2003).

\subsection{Green infrastructure}

A greenway is, in simplest terms, a linear open space. It is a kind of corridor composed of natural vegetation or at least vegetation that is more natural than in surrounding areas. The common characteristics of greenways are that they all go somewhere simply because, by definition, they are linear and natural. Greenways often follow natural land or water features like ridges or rivers, and link natural reserves, parks, cultural features, and historic sites with each other and with populated areas. A community's green infrastructure is a concept that highlights the importance of the natural environment in decision about land use planning. In particular there is an emphasis on the 'life support' functions provided by a network of natural ecosystems, with an emphasis on interconnectivity to support long term sustainability, while gray infrastructure consists of roads, sidewalks, buildings, and utilities. Now, green way planning has become a worldwide movement, and has been embraced by governmental agencies, non-governmental organizations and academies, but, perhaps most importantly, by citizens of urban areas and small towns. The focus is now on the demands of the increasing number of inhabitants and their requirement for recreational areas. Greenways are networks of land that are planned, designed and managed Greenways are networks of land that are planned, designed and managed for multiple purposes compatible with the concept of sustainable land use (Ahern, 1996).A comprehensive set of definition on greenway was provided by Charles Little, the author of the popular 1990 book Greenways for America. In this book a greenway is defined as: linear open space established along either a natural corridor, such as a riverfront, stream valley, or ridgeline, or overland along a railroad right-of-way converted to recreational use, a canal, scenic road, or other route. An openspace connector linking parks, nature reserves, cultural features, or historic sites with each other and with populated areas. Locally certain strip or linear parks designated as parkway or greenbelt (Little, 1990) perhaps the most widely accepted contemporary definition or statement on greenways in the USA was included in the report of the President's Commission on Americans Outdoors in the USA (1987). The Commission advocated a greenways network: to provide people with access to open spaces close to where they live, and to link together the rural and urban spaces in the American landscape threading through cities and country sides like a giant circulation system. It also reflects the late twentieth century orientation in contemporary American land preservation, which focuses on open lands that are directly accessible to population centres, in contrast with the nineteenth and early twentieth century emphasis on the great, but more remote, national parks and other protected landscapes (Zube 1975). The origin of greenway planning goes back to the 1700 till beginning of $20^{\text {th }}$ century. The first generation of greenways is the axes, boulevards, and park ways were affected from ceremonial medieval Roman Axes which were connecting seven churches as sacred way to each other to experience of sequential vision and linking fragmented site. Then magnificent axial boulevards effected from Baroque Planning to symbolize Empire power was designed (Baron Haussmann's boulevard planning). In the United States, Fredrick Law Olmsted was well known. Patrick Abercrombie championed the idea of a Green Belt and Green Wedges around London. The second generation of greenways was reaction to industrialization and motorized route and was developed between 1960s and mid 1980s, as car became the dominant form of travel vehicle. Planner and designer were seeking, linear park and corridors, riversides, riparian ways, and all routes which were none motorized as an ideal proposal for protecting and linking a wide variety of cultural, recreational resources. With beginning of ecology movement in 1980, the concept of greenway changed. Organizations like Greenpeace were more radical, taking direct action against environmental destruction. Its views on people, behaviors, events centered around the political and lifestyle implications of the science of ecology and the idea of nature as a value in itself. "Ecology movement" is an umbrella term for different groups, ideologies and attitudes.According to Searns (1995), third generation of green ways are corridors of land and water that protect and link a wide variety of natural, cultural, and recreational resources. Greenways are corridors of protected open space that are managed for conservation or recreation purposes. They follow natural land and water features, like ridges or rivers, or human landscape features like abandoned railroad corridors or canals and link natural reserves, parks, cultural and historic sites with each other, in many cases with populated areas.

\subsection{Pedhieos River}

Over this long historic period the Nicosia has been a living legacy of the island's rich heritage and contains some of its finest example of byzantine, French Medieval, Venetian, Ottoman and British colonial architecture. At present Nicosia is divided by the buffer zone that keeps the Greek Cypriot and Turkish Cypriot inhabitants apart and splits their town into two separate urban parts, which have been developing independently of each other thus causing the disintegration of its entity. During the medieval period, until 1567Lefkosa Creek used to flow through the Venetian walled city of Nicosia, but it was later diverted outside and inside the newly built moat for strategic reasons, due to the expected Ottoman attack. From 1570 when the Ottomans took over Nicosia, the old river bed through the walled city was left open and was used as a dumping ground for refuse, where rainwater would rush through cleaning it temporarily. In 1882, during the British period, the old river-bed was covered for hygienic reasons (Attalides 1981). This Creek has wonderful ecological qualities. A sustainable tourism development is widely seen as a solution to the problem of island tourism. This may be achieved through more effective control over development at the national level, higher public investment in infrastructure, facilities and environmental improvements in resort areas in order to improve the quality of the overall tourist experience. Promoting tourism products successfully requires a context that allows the audience to appreciate what the country has to offer to visitors. That context is the overall image, or brand of a country. Therefore it can be utilized into creating and developing a new tourism resource such as an ecology tour for native plants while restoring the damaged ecosystem. It is promoted to grant a beauty of scenery and an environment friendly image of Lefkosa city. It secured a green space by using a stream, which serves as a buffing space between the old city and the new city designed for a learning place about ecosystem. It can also be utilized as an experience 
oriented class room where visitors can learn about the characteristics of habitats for different kinds of plants. It also helps the Lefkosa city promote its image as a garden city with a big scale greenway design .It is largely composed of a cultural experiencing zone, an ecology experiencing zone, and leisure zone.

\section{DESIGN APPLICATION}

\subsection{Element of Pedhieos River}

This part of research tries to show elements of a place which make strong image in different scale and level for promoting place identity as important factor in a space, so it is vital to recognize those elements. If we consider a place beyond something two-dimensional, like a living creature that has body and life. The Creek body can be studied in three scales of macro, medium and micro level and people, activities, smells, scents and sounds and other mental and sentimental as well as social, environmental, economical and political aspects that constitute a space in its generality.

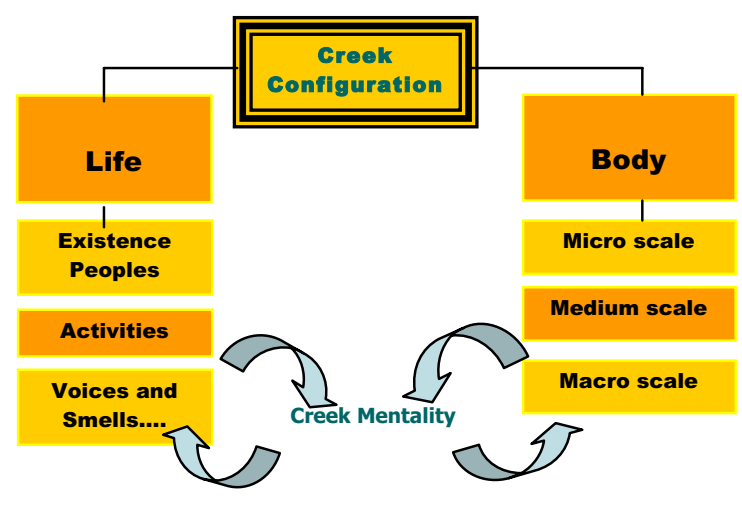

Table No.1 Element of Lefkosa creek

\subsection{Macro scale: Evolvement of fabric in to the space}

Since the approach to structure is in macro scale, it is free of details. Its components are either natural things such as topography, water, trees and vegetation, or manmade such as buildings and spaces, etc. These are seen from high-rise strategic points.

\subsubsection{Components elements in macro scale}

Entrances and Exits: Special design needs for entrance to create welcome feeling for visitors. In greenway design according to project division in different phase, symbolizes the main entrance through ornamental planting, using evergreen ornamental trees, which provide shades so it is used as a meeting and resting point, and traditional elements such as traditional main gate and fence walls. It offer leisure and sports space and consist of an exhibition and promotion theatre to attract the participation of citizens.

Solid and Void: Because of special topography, sculptural play of mass and space can be considered according to artistic principles.

Skyline and Silhouette: another important factor which in this scale make a strong image for percipient in reminding a place

2.3. Medium Scale: An image of visual factors which remain in percipient's mind
In this scale such factors should be interpreted that remain in percipient's mind as an image. These factors may be a single building, transitory, a borderline separating part, a tree, bushes, an attractive locality center or even the locality itself with certain features. In other words, such factors help the individual to read and find his way. Images associated with memories and meanings. They can provide the raw material for the symbols and joint memories and for group communications of the human beings. It is a natural panorama that leaves an outstanding memory in our mind, and creates a background that the majority of the primitive tribes have made their important social fables based on such foundation. These scenes are engraved in the minds of the beholders through the following factors (Lynch, 1997).

\subsubsection{Components elements in medium scale:}

Studies about component elements in medium scale consistently confirm Lynch's (1960) five types of physical elements, including:

Land mark: These are factors distinctive from their surrounding environment for reasons of antiquity, height, design, performance; etc. Creek can present symbolism and identity as Cypriot landmark

Networks Pathways: It is a factor that facilitates practical and potential movements such as trails, roads, sidewalks, roads, underground passageways, railways. These links encourages people to use alternative means of transportation like walking, bicycling and running. Greenway can be used as one way to harmonize various means of transportation and interweave the interaction of pedestrians and automobiles.

Edge: Another factor that divides part of a city from another part such as splits, railway, highway and rivers greenway. Creek as a natural edge offer leisure and sports space and consist of an exhibition and promotion theatre to attract the participation of citizens.

Node: Focal point of activity where people can gather and perform activities such as a park or public square are represented by nodes whereas physical objects that are considered to be only visual point of reference are represented by landmarks(Lynch,1960).

District: Illustrates medium to large parts of the city that are recognizable as having some common perceived character or identity such as an industrial area or a historic neighbourhood. Limitation encroachment of the riparian buffer zone through education, cooperation and incentive program. Keeping riparian corridor intact and continuous along the length of the stream.

2.3 Micro Scale: Those visual factors of body when is noticed immediately after entry the place

It is comprised of the clearest visual factors in a space that are seen immediately after stepping into the place. In other words, all observable elements seen at close range are classified in this category.

\subsubsection{Effective Factors in this scale}

Elevations: can be defined; the projection of the building which are by the side of Creek on vertical plane. The important factors in this scope are considered as follow:

Design, Method of construction, Construction materials, Colour and texture, Construction structure

Space: Space surrounded by mass, a breathing lung and openness. In relation with texture, they may open themselves or 
be in contradiction with it. The spaces are classified into the following: Public, Semi-public, Private, Semi-private

Furniture: Floorings, panels, trees, plants, flowers, shelters, fences, lampposts, fountains, benches, kiosks, posters and announcements, boards, statues, post office boxes, garbage can, bicycle ridding signs etc. as urban furniture are considered in this scale.

\section{Effective Factors in Improving Urban Furniture:}

Design, Direction and orientation, Colour and texture

Mentality: The collection of container and content or body and life, which forms a place mentality.

\section{AIMS, GUIDELINES, AND POLICIES}

As a result the function of greenways are essential and due to scale, aims, context, views, lifestyle, income level, educational background and vocation situation and regulations which planner and designer consider is changeable .In respect of literature study and field study planning and design of Lefkosa creek as a place of tradition, culture and art with historical and cultural symbols can be considered a strong image of place identity in branding city. The concept of traditional culture has been adapted metaphorically from different sceneries related to the Cyprus,history,climate,geoplitical situation and etc.natural historical and cultural greenway can be defined in a broad sense. The aims, guidelines and different policies in design of Lefkosa creek as a cultural historical, Recreative greenway, changing scene, moving landscape, presentation of local /spatial identity can be summarized as follow:

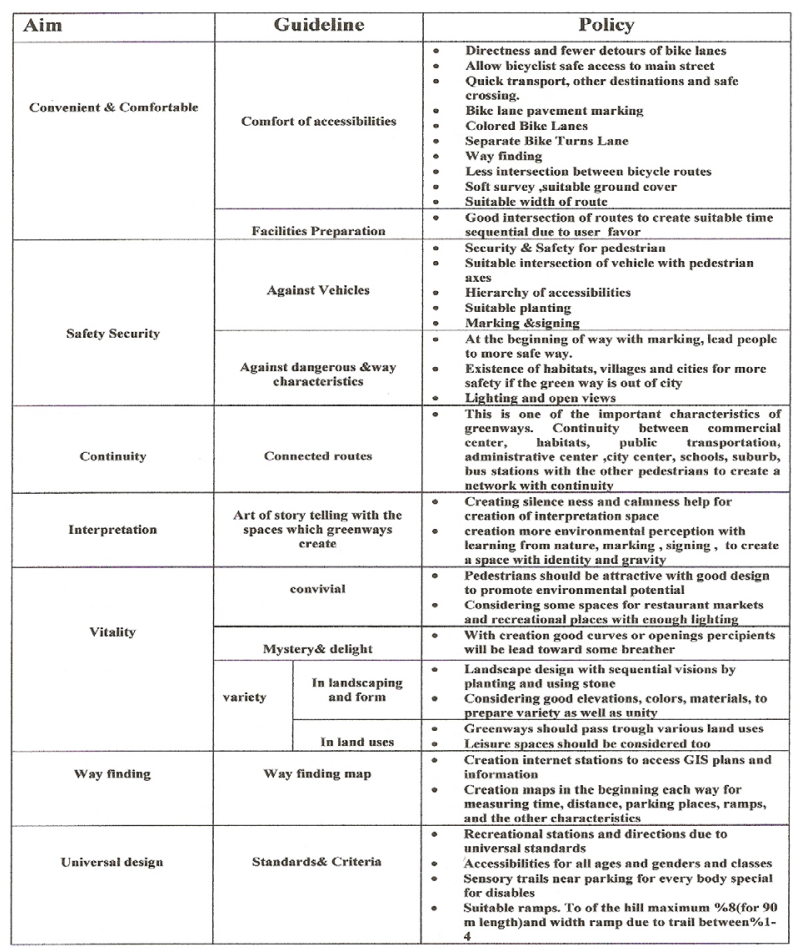

Table No.2 Aims, Guidelines, and Policies

\section{CONCLUSION}

Greenway are not only a tool to preserve and exhibit our past, they give the public access to historic feature while at the same time, provide educational opportunities and protect and preserve resources for future generations. This can be another solution for increasing competiveness by re-positioning Cyprus as a tourism destination; in particular, less emphasis to be placed on sun-sand tourism, whilst attention is to be focused on developing products, such as agro tourism, that are based around the island's culture ,natural environment and people. In general, marketing the island as a mosaic of nature and culture, a whole, magical world concentrated in a small warm and hospital island in the Mediterranean at the crossroad of three continents, between West and East that offers a multidimensional qualities tourist experience. Storm water design and management can be part of a larger plan for the revitalization of this area and to help direct future growth while improving the water quality and ecology of Lefkosa Creek.

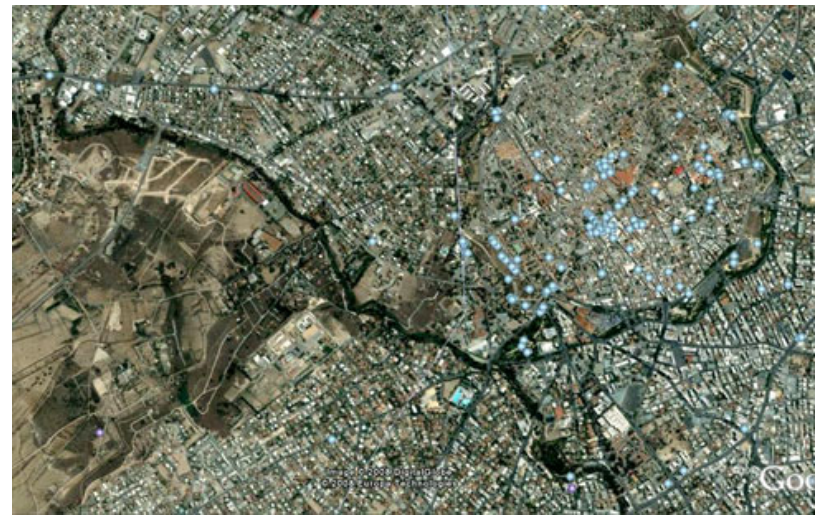

Fig.1.Lefkosa Creek in relation with old City of Nicosia

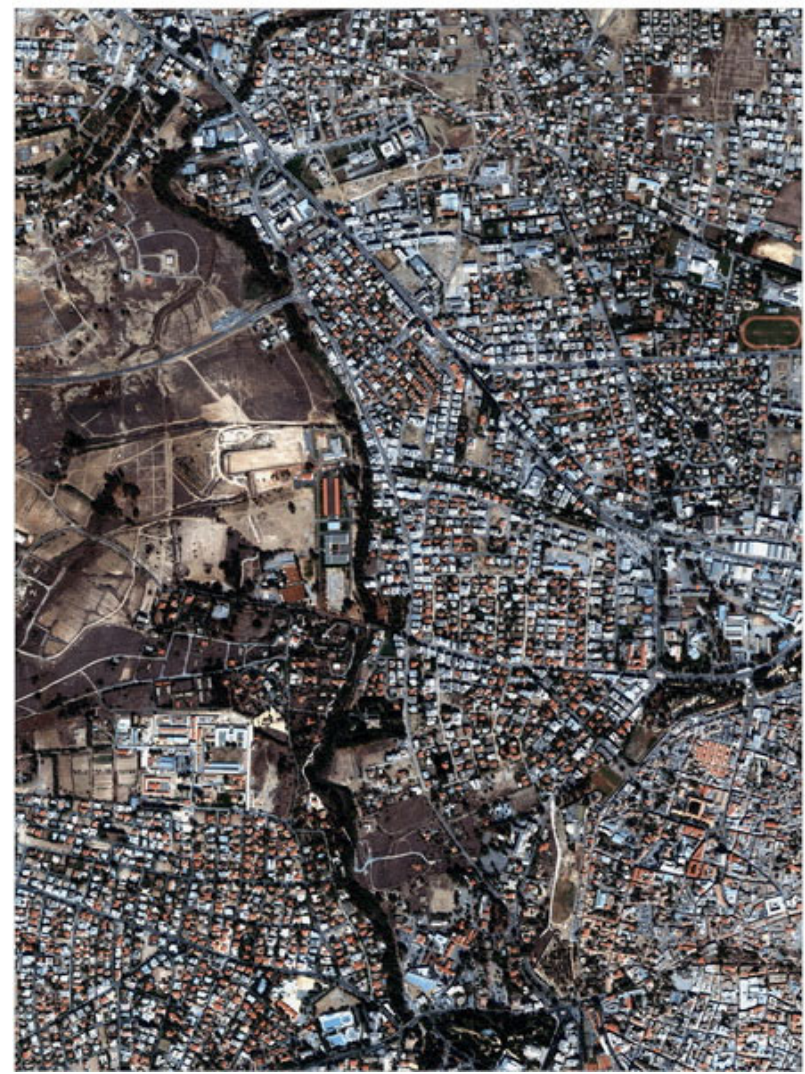

Figure.2 Bird view of Lefkosa Creek 


\section{REFERENCES}

Ahern, J., (2003), Greenway in USA: theory trend and prospect, University of Massachusetts, Amherst, USA

Ahern, J., Fabos, J.G. (1996) Greenways: the beginning of an International Movement, Elsevier, Amsterdam,

Anholt, S. (2006) Competitive Identity: A new model for the brand management of nations, cities and regions, Palgrave Macmillan

Ashworth, G.J (1994) Marketing of Places: What Are We Doing? In G. Ave \&F. Corsico, eds., Marketing Urbano International Conference, Edizioni Torino Incontra, Turin Ashworth, G.J. \& B.J. Graham (2005) Senses of place: senses of time Ashgate, Aldershot

Attalides, M. (1981).Social changes and urbanisation in Cyprus, Nicosia: n. p.

Bacon, Edmund. (1967) Design of cities, first published in Great Britain by Thames and Hudson Ltd. London.

Barth, F. (1995) Ethnicity and the Concept of Culture, Non violent Sanctions and Cultural Survival, Affair Harvard

Brown, A. Theodore and Dorestt Lyle W (1978) K.C A History of Kansas City, Missouri; Pruett Publishing Company, Boulder, Colorado, pp. 163-4.

Culbertson, Kurt (2000)George Edward Kessler Landscape Architect of the American Renaissance In Midwestern Landscape Architecture, W.H. Tishler, ed., Urbana: University of Illinois Press, pp. 99.

European Greenways Association (A.E.V.V./E.G.W.A) (2000) The European Greenways Good Practice Guide: Example of Action Undertaken in cities and Periphery

Fabos, J.G (1979) Planning the Total Landscape: a Guide to Intelligent Land Use Westview Press, Boulder, CO, USA.

Fabos, J.G (1991) from parks to greenways into the 21st Century. In: Proceedings from Selected Educational Sessions of the 1991/ASLA Annual Meeting, ASLA, 4401 Connecticut Avenue, Washington DC.

Fabos, J.G .Ryan, R.L., (2006) An introduction to greenway planning around the world, Elsevier, Landscape and Urban Planning, Editorial 76(2006)1-6

Fabos, J.G .Ryan, R.L., (2004) International greenway planning: an Introduction, Elsevier Landscape and Urban Planning

Fabos, J.G (2004) Greenway planning in United State its origins and recent case studies, Elsevier Landscape and Urban Planning 68(2003) 321-342

Fowler, P.J (2003) World Heritage Cultural Landscapes 1992 - 2002. UNESCO World Heritage

Gibson, W.S (1989) Mirror of the Earth: The World

Landscape in Sixteenth-Century Flemish Painting.Princeton University Press, Princeton, New Jersey

Habib, Fereshteh (2002) Introduction and Recognition Cultural impacts in Configuration of the Urban Structure, Doctoral thesis Science and Research branch of IAU, Ira. Habib, Fereshteh (2007),A Socio-Cultural Attempt in perception the Urban Space, Doctoral Thesis in Architecture Department of Architecture, Faculty of Architecture, Eastern Mediterranean University October) Habib, Fereshteh (2008) Kerpic08, Learning from Earthen Architecture in climate change, International conference, Cyprus International University, Lefkosa, 4-5 September. Hall, Edward. (1997) Hidden Dimension, translated by Tabibian, Manoochehr, Tehran University publication, Tehran, Iran

Harrison, D. (1998) The Sociology of Modernization and
Development. London: Rutledge.

Ioannou, Yannis E. (1997), UNESCO Courier, May.

Ivask, Ivar (1975) Books abroad, vol.49, Norman, Oklahoma, autumn.

Kavaratiz, M. And Ashworth, G.J. (2005), City Branding: An Effective Assertion of Identity or a Transitory Marketing Trik?,Tijdscrift Voor Economische en Sociale Geografie,Vol.96,No.5,pp.506-514

Kavaratiz, M. (2005), From City Marketing to City Branding: Towards a Theoretical Framework for Developing City Brands, Place Branding, Vol.1, No. 1, pp. 58-73

Kavaratiz, M. (2005), Place Branding: A Review of Trend and Conceptual Models, The Marketing Review, Vol.5, No.4, pp.392-342

Keshishian, K. (1990) Nicosia: capital of Cyprus then and now, Nicosia: Mouflon.

Landscape and Urban Planning, Editorial 76(2006)1-6

Landscape and Urban Planning 68(2003) 321-342

Little, C.E., 1990 Greenway for America John Hopkins University Press, Baltimore, MD

Lych M.R. (1998) Culture and sustainable urban development, Sax University Study Organization, England, National commission of UNESCO

Lynch, k. (1993) Image of city, translated by Mozayani, Manoochehr, Tehran University publication, Tehran.

McHarg, I.L., (1969) Design with Nature. The Natural History Press, Garden City, New York, USA

PANNELL, S (2006) Reconciling Nature and Culture in a Global Context: Lessons form the World Heritage List. James Cook University, Cairns. Page 63

Searns R.M. (1995) Evolution of Greenways as an Adaptive Landscape Form

Sharpley, R. (2003) Tourism, Modernization and Development on the Island of Cyprus: Challenges and Policy Responses. Journal of Sustainable Tourism, 11:2,246-265

Simoes, C. \& Dibb (2001), Rethinking the Brand Concept. New Brand Orientation Corporate Communications: An International Journal6, pp.217-224.

Zube, E.H., Brush, R.O., Fabos, J.G., (1975) Landscape Assessment: Value, Perception, and Resources. Dowden, Hutchinson and Ross, USA 